\title{
Causative/Inchoative Verb Alternation in Altaic Languages: Turkish, Turkmen, Nanai and Mongolian
}

\author{
Wenchao $\mathrm{Li}^{1}$ \\ ${ }^{1}$ Department of Japanese Studies, Zhejiang University, Hangzhou, China \\ Correspondence: Wenchao Li, Department of Japanese Studies, Zhejiang University, Hangzhou, China. E-mail: \\ widelia@zju.edu.cn
}

Received: July 30, 2020

Accepted: September 25, 2020

Online Published: September 29, 2020

doi:10.5539/ijel.v10n5p399

URL: https://doi.org/10.5539/ijel.v10n5p399

\begin{abstract}
The purpose of the study is two-fold. First, a statistical analysis of the morphology of causative/inchoative verb alternation is carried out in Japanese and in 13 Altaic languages, i.e., Turkish, Turkmen, Nanai, Khakas, Udihe, Uzbek, Sakha, Manchu, Kyrgyz, Mongolian, Kazakh, Ewen, and Azerbaijani. The findings reveal that causative/inchoative verb alternation (a) can be realised via the insertion of an infix ('-uul-', '-e-', '-g-', etc.); (b) can be inchoative root-based, with transitive verbs derived via attaching a suffix to the inchoative verb roots ('-dur-', '-t-', '-ir-', '-dyr-', '-wəən-', '-buwəən-', '-r-', '-wənə-', '-nar-', '-ier-', '-er-', '-bu-', '-vkan-’); (c) can be causative verb-based, with inchoative verbs being derived via attaching a suffix to the causative verb roots ('-p-', '-n-', '-ul-', '-il-'); and (d) can be realised via consonant alternation ('-r-' (transitive) / '-n-' (intransitive); '-t-' (transitive) / '-n-' (intransitive)). This study further attempts to pin down the affiliation of these languages with the Japanese language. It compares the morphological findings with Japanese bound morphemes in causative/inchoative verb alternation and then delves into the phonological issues, i.e., consonant alternation and vowel harmony. A proposal is put forward: phonologically and morphologically, Japanese has a good deal of resemblance to the 13 Altaic languages.
\end{abstract}

Keywords: causative/inchoative verb alternation, morphology, Japanese, Turkic genus, Tungusic genus, Mongolic genus, Nivkh genus

\section{Causative/Inchoative Verb Alternation}

Causative/inchoative verb alternation is distributed in about 16 language families and 80 languages (Note 1), i.e., Indo-European (23 languages), Altaic (13 languages), Tibetan (eight languages), Afro-Asiatic (six languages), Japanese (five languages), Nakh-Daghestanian (four languages), Niger-Congo (four languages), Uralic (four languages), Austronesian (three languages), Kartvelian (two languages), Austro-Asiatic (one language), Basque (one language), Ainu (one language), Burushaski (one language), Chukotko-Kamchatkan (one language), Korean (one language), Nilo-Saharan (one language), and Sino-Tai-Kadai (one language). The Altaic language family has the second largest language tokens: Mongolian, Turkish, Turkmen, Nanai, Khakas, Udihe, Uzbek, Sakha, Manchu, Kyrgyz, Kazakh, Ewen, and Azerbaijani. (1)-(13) provides illustrations of the causative/inchoative verb alternation in Altaic languages.

\section{(1) Mongolian}

\begin{tabular}{|c|c|c|c|}
\hline \multicolumn{2}{|c|}{ Inchoative verb } & \multicolumn{2}{|c|}{ Causative verb } \\
\hline ser-ex & (wake up.intr) & ser-e-ex & (wake up. tran) \\
\hline xajl-ax & (melt. .intr $)$ & xajl-uul-ax & (melt. tran) \\
\hline duus-ax & $\left(\right.$ finish $\left._{\text {intrt }}\right)$ & duus- $g$-ax & (finish. ${ }_{\text {tran }}$ ) \\
\hline
\end{tabular}

(Illustrations are taken from Umetani Hiroaki, 2014)

Mongolian transitivity pairs seem to be inchoative root-based, with transitive verbs being derived via inserting an infix to the inchoative verb roots. 


\section{(2) Turkish}

Turkish transitivity pairs appear to be inchoative root-based, with transitive verbs being derived via a suffix to the inchoative verb roots, e.g., '-dur-', '-t-', '-ir-'.

\begin{tabular}{|c|c|c|c|}
\hline \multicolumn{2}{|c|}{ Inchoative verb } & \multicolumn{2}{|c|}{ Causative verb } \\
\hline uyan & (wake up.intr) & uyan-dir & (wake up. tran) \\
\hline eri & (melt. .intr $)$ & eri- $t$ & (melt. tran) \\
\hline bit & $\left(\right.$ finish.intr $\left._{\text {intr }}\right)$ & bit-ir & $\left(\right.$ finish. $\left.{ }_{\text {tran }}\right)$ \\
\hline
\end{tabular}

(Illustrations are taken from Seval Dirik, Nitta Shiho, Kuribayashi Yuu, 2014)

\section{(3) Turkmen}

Causative/inchoative verbs in Turkmen appear to have two patterns: (a) causative and inchoative verbs share the same word form; (b) inchoative root-based, with transitive verbs derived via attaching a suffix to the inchoative verb roots, i.e., '-dyr-', '-t-'.

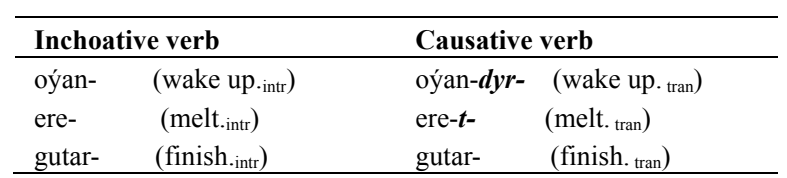

(Illustrations are taken from Oku Masahiro, 2014)

\section{(4) Nanai}

It appears that the alternation in Nanai is of two patterns, i.e., (i) inchoative verbs are the base, causative verbs are derived via attaching a suffix to the inchoative verb roots; or (ii) causative verbs are the base, inchoative verbs are derived via attaching a suffix to the causative verb roots.

\begin{tabular}{|c|c|c|}
\hline Inchoat & e verb & Causative verb \\
\hline $\begin{array}{l}\text { sənə- } \\
\text { uun- } \\
\text { xoȳi-p- }\end{array}$ & $\begin{array}{l}\text { (wake up.intr) } \\
\left(\text { melt. }_{\text {.intr }}\right) \\
\left(\text { finish.intr }_{\text {.ing }}\right)\end{array}$ & 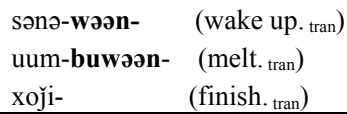 \\
\hline
\end{tabular}

(Illustrations are taken from Kazama Shinjiro, 2015)

\section{(5) Khakas}

Khakas' alternation presents two patterns, i.e., (i) inchoative and causative verbs are altered via consonant alternation ('-r-' (transitive) with '-n-' (intransitive)); or (ii) causative verbs are the base, inchoative verbs are derived via attaching a suffix to the causative verb roots.

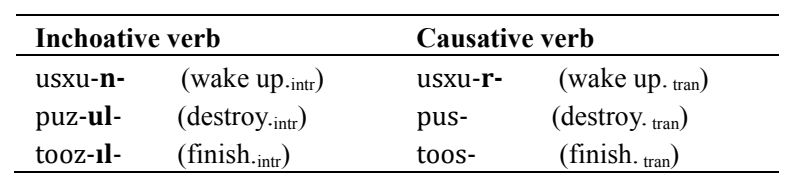

(Illustrations are taken from Oku Masahiro, 2014)

\section{(6) Udihe}

The alternation in Udihe has three patterns, i.e., (i) causative and inchoative verbs take different stems but share the same suffix; (ii) inchoative verbs are the base, causative verbs are derived via attaching a suffix to the inchoative verb roots; (iii) causative and inchoative verbs share the same word form. 


\begin{tabular}{|c|c|c|c|}
\hline \multicolumn{2}{|c|}{ Inchoative verb } & \multicolumn{2}{|c|}{ Causative verb } \\
\hline sələ(gi)- & (wake up. .intr ) & siu(gi)- & (wake up. tran $)$ \\
\hline gəkti- & (freeze.intr) & gəkti-wənə- & (freeze. $\operatorname{tran})$ \\
\hline wadi- & (finish.intr) & wadi- & (finish. tran ) \\
\hline
\end{tabular}

(Illustrations are taken from Kazama Shinjiro, 2015)

\section{(7) Uzbek}

Turning to Uzbek, one option is via consonant alternation: '-t-' (transitive) / '-n-' (intransitive).

Other options are: (a) inchoative verbs are the base, causative verbs are derived via attaching a suffix to the inchoative verb roots; (b) causative verbs are the base, inchoative verbs are derived by attaching a suffix to the causative verb roots.

\begin{tabular}{llll}
\hline \multicolumn{2}{l}{ Inchoative verb } & \multicolumn{2}{l}{ Causative verb } \\
\hline uyg'on- & (wake up. $\left.{ }_{\text {.intr }}\right)$ & uyg'ot- & (wake up. tran $)$ \\
o'rgan- & (learn) & o'rgat- & (teach) \\
tuga- & (finish.intr) & tuga-t- & (finish. tran) \\
buz-il- & (destroy.intr) & buz- & (destroy. tran) \\
\hline
\end{tabular}

(Illustrations are taken from Yoshimura Taiki, 2014)

\section{(8) Sakha}

Sakha transitivity pairs resemble Mongolian and Turkish, i.e., inchoative root-based, with causative verbs derived via attaching a suffix to the inchoative verb roots.

\begin{tabular}{|c|c|c|c|}
\hline \multicolumn{2}{|c|}{ Inchoative verb } & \multicolumn{2}{|c|}{ Causative verb } \\
\hline uhugun & (wake up.intr) & uhugun-nar & (wake up. tran) \\
\hline ir & (melt. intr) & ir-ier & (melt. tran) \\
\hline büt & $\left(\right.$ finish.intr $\left._{\text {. }}\right)$ & büt-er & $\left(\right.$ finish. $\left._{\text {tran }}\right)$ \\
\hline
\end{tabular}

(Illustrations are taken from Ebata Fuyuki, 2014)

\section{(9) Manchu}

Manchu basically presents a pattern whereby inchoative verbs are the base and transitive verbs are derived via attaching a fixed suffix '-bu-' to the inchoative verb roots.

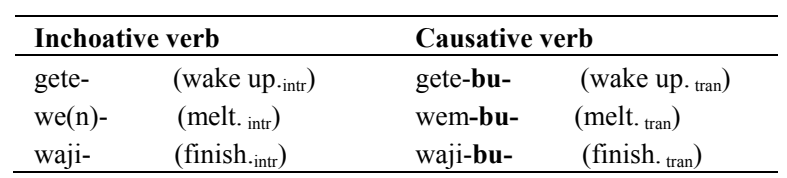

(Illustrations are taken from Kazama Shinjiro, 2015)

\section{(10) Kyrgyz}

\begin{tabular}{|c|c|c|c|}
\hline \multicolumn{2}{|c|}{ Inchoative verb } & \multicolumn{2}{|c|}{ Causative verb } \\
\hline $\begin{array}{l}\text { oygo-n- } \\
\text { eri- } \\
\text { büt }\end{array}$ & $\begin{array}{l}\left.\text { (wake up. }{ }_{\text {.intr }}\right) \\
\text { (melt. intr) } \\
\text { (finish.intr) }\end{array}$ & $\begin{array}{l}\text { oygo-t- } \\
\text { eri-t- } \\
\text { büt-er }\end{array}$ & $\begin{array}{l}\text { (wake up. tran) } \\
\text { (melt. tran) } \\
\text { (finish. tran) }\end{array}$ \\
\hline
\end{tabular}

(Illustrations are taken from Ohsaki Noriko, 2014)

In Kyrgyz, the alternation of causative/inchoative verbs is realised via two ways: (a) consonant alternation ('-t-' (transitive) with ' $-n$-' (intransitive)); (b) inchoative verbs are the base and transitive verbs are derived via attaching a suffix to the inchoative verb roots ('-t-', '-er-'). 


\section{(11) Kazakh}

Kazakh's causative/inchoative alteration is systemic: inchoative verbs are the base and transitive verbs are derived via attaching the suffixes '-t-' or '-ir-' to the inchoative verb roots.

\begin{tabular}{|c|c|}
\hline Inchoative verb & Causative verb \\
\hline oya-n- $\quad$ (wake up.intr $)$ & oya-t- $\quad$ (wake up. tran) \\
\hline (melt. intr) & $($ melt. tran $)$ \\
\hline bit- $\quad\left(\right.$ finish. $\left._{\text {intr }}\right)$ & $\left(\right.$ finish. $\left._{\text {tran }}\right)$ \\
\hline
\end{tabular}

(Illustrations are taken from Ohsaki Noriko, 2014)

\section{(12) Ewen}

In Ewen, causative/inchoative verb alternation seems to display three patterns: (a) causative verb as the base and inchoative verb derived via attaching a suffix to the causative verb roots ('-rkan-'); (b) inchoative verb as the base, with causative verb derived via suffix attachment; (c) causative and inchoative are morphologically unrelated.

\begin{tabular}{|c|c|c|c|}
\hline \multicolumn{2}{|c|}{ Inchoative verb } & \multicolumn{2}{|c|}{ Causative verb } \\
\hline mial & (wake up. .int $_{\text {) }}$ ) & xeru- & $({\text { wake up. } \text { tran })}$ \\
\hline Il- & $($ stop. intr $)$ & Il-okan- & (stop. tran) \\
\hline xaаju-p- & $($ destroy.intr $)$ & xaаjo- & $($ destroy. $\operatorname{tran})$ \\
\hline
\end{tabular}

(Illustrations are taken from Kazama Shinjiro, 2015)

\section{(13) Azerbaijani}

The alternation of causative/inchoative verbs seem to be realised in two ways: (a) consonant alternation (/t/ (causative) with $/ \mathrm{n} /$ (inchoative)); (b) inchoative verbs are the base, causative verbs are derived by attaching the suffix / $/$ / or /ir/ to the inchoative verb roots.

\begin{tabular}{llll}
\hline \multicolumn{2}{l}{ Inchoative verb } & \multicolumn{2}{c}{ Causative verb } \\
\hline oyan- & $\left(\right.$ wake up. $\left.{ }_{\text {.intr }}\right)$ & oyat- & $($ wake up. tran $)$ \\
ori- & $($ learn $)$ & orit- & (teach) \\
bit- & $\left(\right.$ finish.intr $\left._{\text {. }}\right)$ & bit-ir- & $($ finish. tran $)$ \\
\hline
\end{tabular}

(Illustrations are taken from Yoshimura Taiki, 2014)

As agglutinative languages, morphology plays an essential role in Altaic languages. Despite that the above data are limited, they suggest the following rules:

a. Causative/inchoative verb alternation can be realised via the insertion of an infix. This pattern is particularly observed in Mongolian, where the infixes are '-uul-', '-e-', '-g-', etc.

b. Causative/inchoative verb alternation can share the same word form, as seen in Turkmen and Udihe.

c. Causative/inchoative verb alternation can be inchoative root-based, with transitive verbs derived via attaching a suffix to the inchoative verb roots. The suffixes are '-dur-', '-t-', '-ir-', '-dyr-', '-wəən-', '-buwəən-', '-r-', '-wənə-', '-nar-', '-ier-', '-er-', '-bu-', '-okan-'. This pattern is the most common form, i.e., in Nanai, Turkmen, Turkish, Sakha, Manchu, Kyrgyz, Kazakh, and Ewen.

d. Causative/inchoative verb alternation can be causative verb-based, with inchoative verbs being derived via attaching a suffix to the causative verb roots. The intransitivisation suffixes are '-p-', '-n-', '-ul-', '-il-'. This pattern is employed in Khakas, Nanai, and Uzbek.

e. Causative/inchoative verb alternation can be realised via consonant alternation: '-r-' (transitive) / '-n-' (intransitive); '-t-' (transitive) / '-n-' (intransitive).

f. Causative and inchoative verbs take different stems but share the same suffix, as seen in Udihe.

This having been said, the above are merely primary findings. This study carries out a corpus-based investigation 
of 13 Altaic languages, delving into the morpho-syntactic features of causative/inchoative verb alternation. With this in place, we compare the alteration patterning, as well as the bound morphemes that convey the alternation, with Japanese, which is also a morphologically agglutinative language, with a transitive/unaccusative verb alternation system rendered by morphemes.

This study aims to pin down the morphological features of causative/inchoative verb alternations in 13 Altaic languages. Building on this, it further explores whether Japanese could be categorised as a member of the Altaic language family.

The data for Turkish, Turkmen, Mongolian, Nanai, Khakas, Udihe, Uzbek, Sakha, Manchu, Kyrgyz, Kazakh, Ewen and Azerbaijani are extracted from The World Atlas of Transitivity Pairs, provided by the National Institute for Japanese Language and Linguistics. The data for Japanese are drawn from the corpus of the BCCWJ (Balanced Corpus of Modern Written Japanese) by the National Institute for Japanese Language and Linguistics.

This paper is structured as follows. Section 2 summarises typological work on causative/inchoative verb alternation in the past. Section 3 presents quantified data, delving into the bound morphemes that play an essential role in Altaic languages and in Japanese. Section 4 poses the questions of whether Japanese ought to be alleged as an Altaic language. The geographic, phonological and morphological aspects are addressed. Section 5 highlights the results and concludes the paper.

\section{Previous Work on Causative/Inchoative Verb Alternation}

Causative/inchoative verb alternation has been studied intensively in linguistic typological work since 1969 (Nedjalkov and Silnitsky 1973, Jacobsen 1985, Croft 1990, Haspelmath 1993, Kageyama 1996, Comrie 2006, etc.). This boom was kicked off by the publication of Nedjalkov (1969), in his paper Nekotorye verojatnostnye universalii v glagol'nom slovoobrazovanii. Cross-linguistic studies of causative/inchoative verb alternation mainly focus on two aspects: (a) synchronically, how morphologically the two forms are related; (b) diachronically, which is the base root and how the other is derived. A great deal of effort has been put in to conducting these inquiries: see, for instance, Masica (1976), who conducted an investigation into the distribution of transitive and intransitive verbs, in an effort to arrive at an understanding of the derivation direction. Haspelmath (1993) observed 20 pairs of transitive/intransitive verbs of different languages and put forward an intra-linguistic and a cross-linguistic path of the derivation. Beth Levin has contributed to the study of verbs from perspectives such as 'lexical conceptual structure', 'event structure', and 'scalar structure' (1991, 1996, $1998,2005,2010$, etc.). One contribution that is related to the present study is the 'lexical-semantic'-based proposal: 'manner/result complementarity' (Rappaport Hovav and Levin 2010: 25). According to this proposal, a verb root can only be associated with a single position in an event schema, and since manner and result roots are associated with distinct positions, a verb lexicalises either manner or result. This insight further links to the scalar structure in that result roots specify scalar changes and manner roots do not (Rappaport Hovav and Levin 2010):

(14) Manner/result complementarity in relation with scalar change

\section{a. Manner verb}

amble, crawl, hop, jog, limp, run, swim, walk

\section{b. Result verb}

arrive, come, enter, exit, fall, go, rise

Manner/result complementarity applies to Japanese verbs, i.e., the manner verb corresponds to the causative verb (e.g., kowa-s-(r)u; kir-O); and the result verb applies to the inchoative verb (e.g., kowa-re-ru; kir-e-ru.). An illustration of Japanese and English is provided in (15).

(15) Manner/result complementarity in Japanese

a. Haha ga keeki o yaita (causative verb: manner)

b. Keeki ga yaketa (inchoative verb: result)

a'. Mummy baked a cake (causative verb: manner)

b'. *A cake baked (inchoative verb: result)

Kageyama $(1993,1996)$ applies a 'lexical conceptual structure' to the study of Japanese transitivity pairs and proposes that Japanese causative/inchoative verb alternation displays two patterns: 'anticausativisation' and 'decausativisation'. Anticausativisation refers to the object changing in terms of the property of the object itself. The transitive verb takes on an intransitive function via identifying the object and causer, e.g., waru/wareru; 
yaburulyabureru, etc.

\section{(16) Anticausativisation}

$$
\begin{aligned}
& x \quad \text { CONTROL }\left[\begin{array}{lllll}
y & \text { BECOME } & {\left[\begin{array}{lll}
y & \mathrm{BE} & \mathrm{AT}-z
\end{array}\right]}
\end{array}\right] \\
& x=y \\
& \text { e.g., } \text { warutrol }
\end{aligned}
$$

Decausativisation refers to the object changing in terms of external factors. The intransitivisation affix '-ar-' suppresses the causer in the semantic structure and thus, the syntactic structure is covert. Through this manipulation, transitive verbs take on an intransitive function.

\section{(17) Decausativisation:}

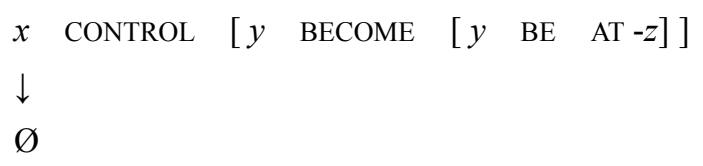

To sum up briefly, the manipulation of anticausativisation indicates a change of state that takes place spontaneously, whilst decausativisation involves agentivity (intention).

NINJAL (2014) carried out a geo-typological investigation (i.e., WATP) and generalised five alternation patterns: (a) anticausative type; (b) causative type; (c) equipollent type; (d) labile type; (e) suppletive. Table 1 presents the

\begin{tabular}{|c|c|c|}
\hline Direction of derivation & Expression type & Formal relationship between the members of the transitivity pair \\
\hline \multirow[t]{2}{*}{ Directed } & A (Anticausative) & $\begin{array}{l}\text { Transitive verb is basic from which the intransitive counterpart is } \\
\text { formally derived (Detransitivisation) }\end{array}$ \\
\hline & $\mathrm{C}$ (Causative) & $\begin{array}{l}\text { Intransitive verb is basic from which the transitive counterpart is } \\
\text { formally derived (Transitivisation) }\end{array}$ \\
\hline \multirow[t]{3}{*}{ Non-directed } & E (Equipollent) & Both transitive and intransitive verbs are marked \\
\hline & L (Labile) & Transitive and intransitive verbs are formally identical \\
\hline & $\mathrm{S}$ (Suppletive) & The transitive and intransitive verbs are formally distinct and underived \\
\hline
\end{tabular}
morphological relationship between inchoative and causative verbs in each type.

Table 1. Morphological relationship between inchoative and causative verbs

Inspired by WATP's macro classification, the present study delves into a delicate matter, i.e., the bound morphemes that render causative/inchoative verb alternation, and whether Japanese has a phonological and morphological resemblance to the 13 Altaic languages.

\section{Morphological Study of Causative/Inchoative Verb Alternation in Altaic Languages}

The targeted 13 languages fall into four genera:

(a) Turkic languages: Kyrgyz, Khakas, Kazakh, Azerbaijani, Uzbek, Turkish, and Turkmen

(b) Tungusic languages: Ewen, Nanai, Udihe, and Manchu

(c) Mongolic languages: Mongolian

(d) Nivkh languages: Sakha

The investigation selects 31 lexicons as candidates. The English translations of these lexicons are: boil, freeze, dry, wake up, go out/put out, sink, learn/teach, melt, stop, turn, dissolve, burn, destroy, fill, finish, begin, spread, roil, develop, get lost/lose, rise/raise, improve, rock, connect, change, gather, open, break, close, split, die/kill. The data are drawn from The World Atlas of Transitivity Pairs (provided by the National Institute for Japanese Language and Linguistics).

\subsection{Causative/Inchoative Verb Alternation in Turkic Languages}

Turkic is the largest genus among the Altaic languages, including Kyrgyz, Khakas, Kazakh, Azerbaijani, Uzbek, Turkish, and Turkmen. The causative/inchoative morphemes are summarised in Table 2. 
Table 2. Causative/inchoative morphemes in Turkic genus

\begin{tabular}{|c|c|c|c|c|c|c|c|c|c|c|}
\hline \multirow{2}{*}{$\begin{array}{l}\text { Turkic genus } \\
\text { Turkish }\end{array}$} & \multicolumn{5}{|c|}{ Causativisation morpheme (Note 2) } & \multicolumn{5}{|c|}{ Inchoative morpheme (Note 3) } \\
\hline & $\begin{array}{l}\text { /-t-/ (11) } \\
\text { (Note 4) }\end{array}$ & /-dur-/ (8) & /-dir-/ (4) & & & /-il-/ (10) & $/-\mathbf{n}-/(12)$ & /-ol-/ (3) & & \\
\hline Turkmen & /-t-/ (9) & /-dur-/ (4) & & & & & $/-\mathbf{n}-/(3)$ & & /-ül-/ (3) & $\mid-\mathbf{y l}-/(5)$ \\
\hline Khakas & /-t-/ (9) & & /-dir-/ (8) & & & /-il-/ (7) & $/-\mathbf{n}-/(3)$ & & & \\
\hline Uzbek & /-t-/ (10) & & /-dir-/ (5) & & & /-il-/ (7) & $/-n-/(5)$ & & & \\
\hline Azerbaijani & /-t-/ (9) & /-dur-/ (4) & & /-ir-/ (3) & & /-il-/ (8) & $/-n-/(7)$ & & /-ül-/ (4) & \\
\hline Kyrgyz & /-t-/ (13) & & & & /-tür-/ (4) & /-il-/ (6) & & & /-ül-/ (6) & \\
\hline Kazakh & $/-t-/(15)$ & & /-dir-/ (3) & /-ir-/ (3) & & /-il-/ (11) & $/-\mathbf{n}-/(3)$ & & & \\
\hline
\end{tabular}

In the Turkish genus, the morpheme '-t-' plays an essential role in causativisation. It is employed by all languages and bears the largest token numbers. The next causativisation morpheme is '-dir-' (seen in four languages); the thirdly used morpheme is '-dur'. Moreover, we noted the following additional suffixes: /-ir-/ and /tür/. Regarding the inchoative morpheme, the most used morpheme is /-il-/. The second most often employed morpheme is /-n-/. Other intransitivisation morphemes are /-ül-/ and /-yl-/.

\subsection{Causative/Inchoative Verb Alternation in Tungusic}

The Tungusic genus has four languages: Ewen, Nanai, Udihe, and Manchu.

\begin{tabular}{|c|c|c|c|c|c|c|c|c|c|}
\hline \multirow{2}{*}{$\begin{array}{l}\text { Tungusic } \\
\text { genus } \\
\text { Ewen }\end{array}$} & \multicolumn{5}{|c|}{ Causativisation morpheme (Note 5) } & \multicolumn{4}{|c|}{ Inchoative morpheme (Note 6) } \\
\hline & & & & & & /-p-/ (9) & $/-n-/(1)$ & & \\
\hline Nanai & /-wəən-/ (5) & /-waan-/ (2) & /-oan-/ (2) & /-wu-/ (2) & /-1i-/ (3) & $/-p-/(6)$ & & /-biə-/ (1) & /-ə-/ (1) \\
\hline Udihe & /-wənə-/ (10) & /-wana-/ (3) & & & & $/-p-/(1)$ & & & \\
\hline Manchu & & & & & /-bu-/ (26) & & & & \\
\hline
\end{tabular}

In the Tungusic genus, the morpheme /-wəən-/ plays an essential role in causativisation. It is employed by Ewen, Nanai, and Udihe. The second most often used causativisation morpheme is /-waan-/. The Nanai language additionally presents three other causativisation morphemes: /-oan-/ and /-wu-/ and /-li-/. In Manchu, inchoative verbs are the base and the causative verbs are derived by the fixed suffix /-bu-/.

Regarding the inchoative morpheme. The most used morpheme is /-p-/. The second most often employed morpheme is /-n-/. Other intransitivisation morphemes are /-biə-/ and /-ə-/.

\subsection{Causative/Inchoative Verb Alternation in Mongolic}

The Mongolian genus has one language, i.e., Mongolian. Two alternation patterns are confirmed. First, inchoative verbs are the base, with causative verbs being derived via inserting an infix into the inchoative verb roots. The infixes include: /-g-/, /-ö-/, /-a-/, /-e-/, /-uul-/, /-o-/, /-üül-/. This pattern takes the majority tokens of the data. The other tokens go to the pattern whereby causative verbs are the base, with inchoative verbs being derived via inserting an infix into the inchoative verb roots: /-r-/, /-gd-/.

\subsection{Causative/Inchoative Verb Alternation in Nivkh}

The Nivkh genus only has one language, i.e., Sakha. Two patterns are observed. First, inchoative verbs are the base, with causative verbs being derived via a suffix to the inchoative verb roots. The suffixes include: /-ar-/, /-t-/, /-or-/, /-er-/, /-üt-/, /-nör-/. Second, the causative verbs are the base, with inchoative verbs being derived via a suffix to the causative verb roots. The causative suffixes, according to their employed frequency, are: /-un-/ and /-n-/.

\section{Further Inquiry: Affiliation of Japanese}

So far, Section 3 has shed light on the morphological features of Altaic languages' causative/inchoative verb alternation. We are now in a position to verify whether Japanese falls into the Altaic language family.

To begin with, a look at the geographic relationship between Japanese and the targeted 13 Altaic languages appears to be necessary.

\subsection{Linguistic Geography}

Altaic languages used to be distributed across the Altai mountains. A map is provided in Figure 1. 


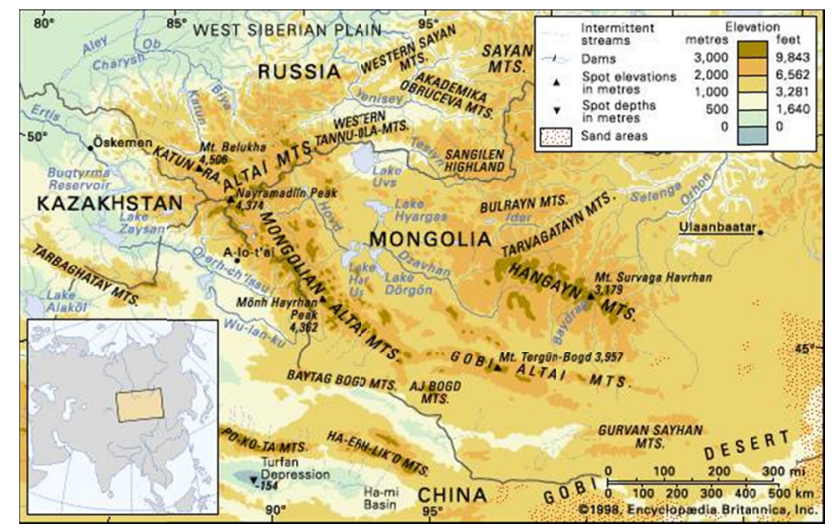

Figure 1. The distribution of Altaic languages (Note 7)

Nomads spread the languages to Turkey and northeastern Siberia. Phonologically, Altaics follow the 'vowel harmony principle': Altaic languages have a diversity of vowels (Note 8), which fall into different groups. Only the vowels that belong to the same group can together form a word.

Morphologically, Altaics are agglutinative. Syntactically, the word order is SOV. The geographic study of Altaic languages begins in 1730, i.e., when von Strahlenberg made a note on the Altaic languages Tungus, Mongolian, and Turkic. Castrén (1854) argued that Samoyedic languages and Finno-Ugric languages should also be included in the Altaic family. This 'Ural-Altaic family' proposal was accepted in the $19^{\text {th }}$ and $20^{\text {th }}$ centuries. The view that Japanese is a member of the Altaic language family was initially put forward by Anton Boller (1857), and Gustaf John Ramstedt and Yevgeny Dmitrievich Polivanov argued that Korean is also an Altaic language. The view that Japanese and Korean are Altaic languages was supported by American linguist Roy Andrew Miller and Russian historical linguist Sergei Anatolyevich Starostin, and recently by Sanchez-Mazas, Blench, Ross, Lin and Pejros (2008), as well as Japanese linguists Hattori Shiroo (1959) and Nomura Masayoshi (1985).

The debate focuses on whether Japanese and Korean are Altaic languages or, Japanese, Korean, Tungus, Mongolian and Turkic languages should fall into a sprachbund relationship (cf. Joseph Harold Greenberg's Eurasiatic languages proposal). To identify a language's affiliation, three aspects ought to be tackled: (a) geographic fact; (b) the historical origin; and (c) linguistic typology. The present study focuses on the linguistic issue. Since morphology plays an essential role in agglutinative languages, we aim to arrive at a result that can support either point of view (i.e., family or sprachbund). In the following sections, the phonological issue (sequential voicing), the morphological issue (causative/inchoative verb alternation), and syntactic derivation are considered.

\subsection{Phonological Point of View}

The investigation starts with two aspects of phonology: (a) the 'vowel harmony principle'; and (b) consonant alternation ('sequential voicing') in Japanese, Mongolian, and Turkish.

\subsubsection{The 'Vowel Harmony Principle'}

A salient phonological feature of Altaic languages lies in the vowel harmony principle. To identify whether Japanese belongs to this group, we ought to delve into the Japanese vowel system. As is known, Modern Japanese vowels are of five types: /a/ , /i/, /u/, /e/, /o/. Old Japanese (Nara Period: 710-94 A.D.) displays a different picture as regards Japanese vowels. The sections below (18)-(21) show the variation of vowels in Old Japanese. They are taken from Bjarke Frellesvig's 'table of orthographically distinct syllables in early Old Japanese'. The characters, i.e., man'yōgana (Note 9), are intended to illustrate the sound of each vowel.

(18) Variation of vowel /i/ in Old Japanese

a. 伊 i, 為 wi, 知 $\mathrm{ti}$, 遅 di, 之 si, 自 zi, 爾 ni, 利 ri

b. 比 $\mathrm{pi}_{1}$, 鼻 $\mathrm{bi}_{1}$, 美 $\mathrm{mi}_{1}$, 支 $\mathrm{ki}_{1}$, 祇 $\mathrm{gi}_{1}$

c. 肥 $\mathrm{pi}_{2}$, 備 $\mathrm{bi}_{2}$, 未 $\mathrm{mi}_{2}$, 貴 $\mathrm{ki}_{2}$, 疑 $\mathrm{gi}_{2}$

\section{(19) Variation of vowel/e/ in Old Japanese}

a. 天 te, 田 de, 勢 se, 是 ze, 尼 ne 
b. 平 $\mathrm{pe}_{1}$, 弁 $\mathrm{be}_{1}$, 売 $\mathrm{me}_{1}$, 家 $\mathrm{ke}_{1}$, 牙 $\mathrm{ge}_{1}$

c. 戸 $\mathrm{pe}_{2}$, 倍 $\mathrm{be}_{2}$, 米 $\mathrm{me}_{2}$, 気 $\mathrm{ke}_{2}$, 義 $\mathrm{ge}_{2}$

\section{(20) Variation of vowel /o/ in Old Japanese}
a. 於 $o$, 乎 wo, 富 po
b. 毛 $\mathrm{mo}_{1}$, 古 $\mathrm{ko}_{1}$, 刀 $\mathrm{do}_{1}$, 度 $\mathrm{do}_{1}$, 俗 $\mathrm{zo}_{1}$
c. 母 $\mathrm{mo}_{2}$, 其 $\mathrm{go}_{2}$, 止 $\mathrm{to}_{2}$, 特 $\mathrm{do}_{2}$, 乃 $\mathrm{no}_{2}$

There are two types of vowels $/ \mathrm{i} /$, $/ \mathrm{e} /$ and $/ \mathrm{o} /$ in Old Japanese, known as koo-rui (type A: $/ \mathrm{i}_{1} / ; / \mathrm{e}_{1} / ; / \mathrm{o}_{1} /$ ) and otsu-rui (type B: $/ \mathrm{i}_{2} / ; / \mathrm{e}_{2} / ; / \mathrm{o}_{2} /$ ). As a result, Old Japanese has eight vowels, i.e., $/ \mathrm{a} /, / \mathrm{e}_{1} /, / \mathrm{e}_{2} /, / \mathrm{i}_{1} /, / \mathrm{i}_{2} /, / \mathrm{o}_{1} /, / \mathrm{o}_{2} /, / \mathrm{u} /$, as does Modern Turkish: /a/, /e/, /o/, /ø/, / $/ \mathrm{w} /, / \mathrm{i} /, / \mathrm{u} /, / \mathrm{y} / . / \mathrm{e}_{1} /, / \mathrm{e}_{2} /, / \mathrm{i}_{1} /, / \mathrm{i}_{2} /, / \mathrm{o}_{1} /, / \mathrm{o}_{2} /$ in Old Japanese did not exist long: in Early Middle Japanese, a period when the pure phonetic script kana was invented, they merged (cf. Bjarke Frellesvig). Modern Japanese vowels are of five types.

The 'Vowel harmony principle' in Modern Mongolian is observed in suffixes and loanwords. Essentially, this involves gender. Ueda (2018) made the following observation: when a loanword's precedent vowel is masculine, a feminine /e/ is required in the suffix; when a loanword's precedent vowel is feminine, a masculine /a/ is required in the suffix. Following this, Old Japanese's two-type vowels would not be referred to as fulfilling the 'vowel harmony principle'. More crucially, Old Japanese is a dead language, therefore even if we admit the existence of the 'vowel harmony principle', no continuity is seen.

This having been said, in Modern Japanese the pronunciation of loanwords presents another picture.

(I). /i/ can render a double vowel with /a/ and /o/, as in (21).

(21) a. voice $\rightarrow$ ボイス /boisu/

$$
\text { b. violin } \rightarrow \text { ヴァイオリン/baiorin/ }
$$

(II). /i/ can render a double vowel with /e/ /, as in (22).

(22) yellow $\rightarrow$ イエロー /ieroo/

(III). /i/ cannot occur with /u/, cf. (23).

(23) suit $\rightarrow$ スーツ/suutsu/ (cf.*/suitsu/)

(IV). /oo/, /ee/ and /ii/ are employed as long vowels:

(24) a. speedway $\rightarrow \quad$ スピードウェイ/supiidowee/

b. Auto-Bi $\rightarrow$ オードバイ /oodobai/

c. east $\rightarrow \quad$ イースト/iisuto/

It appears, then, that Japanese fulfils the 'vowel harmony principle'.

\subsubsection{Consonant Alternation}

The paper now turns to another phonological phenomenon, i.e., consonant alternation (sequential voicing). To start with, consonant alternation refers to the transition of a consonant from an aspirated sound to a voiced sound. In Japanese, this is known as 'sequential voicing', and is conveyed by noun compounds. Kubozono (1999) indicates that Japanese sequential voicing presents the following rules:

(25) a. $/ \mathrm{k} / \rightarrow / \mathrm{g} /$

b. $/ \mathrm{s} / \rightarrow / \mathrm{z} /, / \mathrm{G} / \rightarrow /(\mathrm{d}) \mathrm{z} /$

c. $/ \mathrm{t} / \rightarrow / \mathrm{d} /, / \mathrm{t} 6 / \rightarrow /(\mathrm{d}) \mathrm{z} /, / \mathrm{ts} / \rightarrow /(\mathrm{d}) \mathrm{z} /$

d. $/ \mathrm{h} /, / \mathrm{ç} /, / \phi / \rightarrow / \mathrm{b} /$

There are four restrictions to sequential voicing.

First, different scripts are impacted by sequential voicing in different ways. Indeed, only wago 'kana script' is subject to sequential voicing. Furthermore, sequential voicing is not subject to verb compounds or loanwords. This is illustrated in (26).

(26) a. Wago: aozora 'blue sky'

b. Verb compounds: nakisakebu 'cry-shout'

c. loanwords: bebiikasutera 'bite-sized sponge cakes' 
Second, phonetically speaking, when the $\mathrm{N}_{2}$ contains a voiced consonant, there will be no sequential voicing (cf. Lyman's Law 1894). This is illustrated in (27).
a. soba 'buck wheat'
$\rightarrow \quad$ kitsunesoba 'fried noodles'
b. $t a b a$ 'bundle'
$\rightarrow \quad$ hanataba 'bunch of flowers'
(hand-made examples)

Third, from a morpho-syntactic perspective, when two nouns are assigned to a coordinate relation, sequential voicing is prevented. This is illustrated in (28).
(28) a. oya 'parent' $+o$ 'child'
b. shiro 'white' $\quad+$ kuro 'blc
$\rightarrow \quad$ oyako 'parent-child'
b. shiro 'white' + kuro 'black' $\rightarrow$ shirokuro 'white-black'
(hand-made examples)

The reason for sequential voicing not taking place in the dvandva structure of noun-noun compound may be related to the degree of lexicalisation: lexicalised words are likely to receive sequential voicing.

Finally, the compounding pattern 'object + transitive verb.conjuctive' does not receive sequential voicing, as exemplified by (29).
(29) a. jikan 'time' + tsubushi 'smash'
$\rightarrow \quad$ jikantsubushi 'time-killing'
$\rightarrow$ gohantaki 'food-cooking'
(hand-made examples)

In Turkish, sequential voicing is limited to three consonants, i.e., ᄃ ‘ $/ \mathrm{t}$ ', ㅂ ‘/p/' and 大 ‘/ch/', and thus,

(30) a. $/ \mathrm{t} / \rightarrow / \mathrm{d} /$

b. $/ \mathrm{p} / \rightarrow / \mathrm{b} /$

c. / ç(ch)/ $\rightarrow / \mathrm{c}(\mathrm{j}, \mathrm{zh}) /$

In light of the fact that Japanese presents similar phonological features (vowel harmony principle and consonant alternation) to Altaic languages (Mongolian and Turkish), perhaps we can now contend that Japanese can be deemed phonologically to be an Altaic language. To identify a language's affiliation, historical facts, cultural facts, and sociological facts ought to be taken into consideration. Nonetheless, this study provides evidence from a typological linguistic point of view, suggesting that Japanese is an Altaic language.

\subsection{Morphological Issues}

Now turning to the morphological issue. There are three forms of alternation in Japanese causative/inchoative verb alternation: (a) $v t$ and $v i$ derive from the same adjective stem, e.g., fukai (Adj) $\rightarrow$ FUKAM-ar-u/FUKAM-e-ru; (b) causative and inchoative verbs share the same word form, e.g., HIRA-ku (doa-o-hiraku 'open the door' / doa-ga-hiraku 'the door is open'); (c) a morpheme that indicates $v t$ or vi properties is added to the verb stem (31).

\begin{tabular}{llll}
\hline Intransitive verb & & \multicolumn{2}{c}{ Transitive verb } \\
\hline kir-e-ru & (cut. $\left.{ }_{\text {.intr }}\right)$ & kir- $ø-(\mathrm{r}) \mathrm{u}$ & (cut. $\left.{ }_{\text {tran }}\right)$ \\
-i-/-os-; och-i-ru & (fall) & ot-os-u & (drop) \\
-e-/-akas-; obi-e-ru & (become frightened by) & obiy-akas-u & (frighten) \\
\hline
\end{tabular}

The morphological features that are involved in Japanese causative/inchoative alternation are as follows:

(I) The morpheme '-e-' is used with both intransitive and transitive verbs. In decausativisation, '-ar-' is most frequently used, but other affixes are also acceptable.

e.g., //nur-e-ru//-//nur-as-(r)u//, //kak-ar-(r)u //-//kak-e-ru//, //or-e-ru//-//or- ø-(r)u//,

//at-ar-(r)u//-//at-e-ru//, //yak-e-ru//-//yak-ø-(r)u/, //tat-ø-(r)u//-//tat-e-ru//

(II) The intransitive morpheme '-ar-' tends to covey an ergative verb.

(III) The morpheme '-ar-' represents an intransitive verb and the morpheme of its transitive verb is '-ø-(-u)'or '-e-'.

(IV) The morpheme '-i-' represents an intransitive verb; the morpheme of its transitive verb is '-ø-(-u)' or 
'-os-(-osu)'/ '-as-(-asu)'.

(V) If the morpheme of a transitive verb is '-ø-(-u)', then the morpheme of its intransitive verb would be '-e-'.

(VI) If the morpheme of an intransitive verb is '-e-', then the morpheme of its transitive verb would be '-as-(-asu)' or-s- '(-su)'.

It appears, then, that Japanese's causative/inchoative verb alternation resembles the 13 Altaic languages a good deal, which inspires us to deduce that, morphologically, Japanese ought to be included in the Altaic language family.

\section{Summary}

This study carried out a statistical analysis of causative/inchoative verb alternation in 13 Altaic languages, i.e., Turkish, Turkmen, Nanai, Khakas, Udihe, Uzbek, Sakha, Manchu, Kyrgyz, Mongolian, Kazakh, Ewen, and Azerbaijani. It also discussed the possibility that Japanese is a member of the Altaic language family. The discussion of causative/inchoative verb alternation was divided into four genera:

(i) Causative/inchoative verb alternation in the Turkic genus.

(ii) Causative/inchoatiave verb alternation in the Tungusic genus.

(iii) Causative/inchoatiave verb alternation in the Mongolic genus.

(iv) Causative/inchoatiave verb alternation in the Nivkh genus.

The findings are summarised in Table 3.

Table 3. Variations in causative/inchoative verb alternation in Turkish, Turkmen, Nanai, Khakas, Udihe, Uzbek, Sakha, Manchu, Kyrgyz, Mongolian, Kazakh, Ewen, and Azerbaijani

\begin{tabular}{|c|c|c|c|c|}
\hline Bound morphemes & Turkish genus & Tungusic genus & Mongolic genus & Nivkh genus \\
\hline Causative suffix & $\begin{array}{l}\text { /-t-/,/-dur-/,/-dir-/, } \\
\text { /-ir-/,/-tür-/ }\end{array}$ & $\begin{array}{l}\text { /-wəən-/,/-waan-/,/-oan-/, } \\
\text { /-wu-/,/-li-/,/-bu-/ }\end{array}$ & & $\begin{array}{l}\text { /-ar-/, /-t-/, /-or-/, } \\
\text { /-er-/,/-üt-/,/-nör-/ }\end{array}$ \\
\hline Inchoative suffix & $\begin{array}{l}\text { /-il-/, /-ül-/, /-ol-/, /-n-/, } \\
\text { /-ül-/, /-yl-/ }\end{array}$ & /-p-/,/-n-/, /-biə-/,/-ə-/ & & /-un-/, /-n-/ \\
\hline Causative infix & & & $\begin{array}{l}\text { /-g-/, /-ö-/, /-a-/, /-e-/, } \\
\text { /-uul-/,/-o-/, /-üül-/ }\end{array}$ & \\
\hline Inchoative infix & & & /-r-/,/-gd-/ & \\
\hline Causative/inchoative share the same form & Turkmen & Udihe & & \\
\hline Consonant alternation & '-t-'/'-n-'; & & & \\
\hline $\begin{array}{l}\text { Causative and inchoative are } \\
\text { morphologically unrelated }\end{array}$ & & $\begin{array}{l}\text { Some transitivity pairs in } \\
\text { Ewen }\end{array}$ & & \\
\hline
\end{tabular}

a. Causative/inchoative verb alternation can be realised via the insertion of an infix. This pattern is particularly observed in Mongolian, where the infixes are '-uul-', '-e-', '-g-', etc.

b. Causative/inchoative verb alternation can share the same word form, as seen in Turkmen and Udihe.

c. Causative/inchoative verb alternation can be inchoative root-based, with transitive verbs derived via attaching a suffix to the inchoative verb roots. The suffixes are '-dur-', '-t-', '-ir-', '-dyr-', '-wəən-', '-buwəən-', '-r-', '-wənə-', '-nar-', '-ier-', '-er-', '-bu-', and '-rkan-'. This pattern is the most common option, i.e., appearing in Nanai, Turkmen, Turkish, Sakha, Manchu, Kyrgyz, Kazakh, and Ewen.

d. Causative/inchoative verb alternation can be causative verb-based, with inchoative verbs being derived via attaching a suffix to the causative verb roots. The intransitivisation suffixes are '-p-', '-n-', '-ul-', '-il-'. This pattern is employed in Khakas, Nanai, and Uzbek.

e. Causative/inchoative verb alternation can be realised via consonant alternation: '-r-' (transitive) / '-n-' (intransitive); '-t-' (transitive) / '-n-' (intransitive).

f. Causative and inchoative verbs take different stems but share the same suffix, as seen in Udihe.

Furthermore, the investigation of the phonological issue (vowel harmony and consonant alternation in Old Japanese and Modern Japanese), and the morphological matter (causative/inchoative verb alternation), suggested that, phonologically and morphologically, Japanese presents a great deal of similarity to the 13 Altaic languages, and thus ought to be deemed a member of the Altaic language family. 


\section{Acknowledgements}

This paper is based on work that was supported by the National Foundation of Social Sciences (15CYY002) as well as the Fundamental Research Funds for the Central Universities to Wenchao Li.

\section{References}

Comrie, B. (1976). Aspect. Cambridge: CUP.

Haspelmath, M. (1993). More on the typology of inchoative/causative verb alternations. In C. Bernard \& P. Maria (Eds.), Causatives and transitivity (pp. 87-120). Amsterdam: John Benjamins. https://doi.org/10.1075/slcs.23.05has

Hattori, S. (1959). The system of the Japanese language. Iwanami Publishing Company.

Kageyama, T. (1993). Bunpou to gokeisei. Tokyo: Hitsuji Shobo Publishing.

Kageyama, T. (1996). Verb meaning: language and cognition interface. Kuroshio.

Levin, B. (1991). Building a Lexicon: The Contribution of Linguistic Theory. International Journal of Lexicography, 4, 205-226. Also appears in M. Bates \& R. Weischedel (Eds., 1993), Challenges in Natural Language Processing (pp. 76-98). Cambridge, UK: Cambridge University Press.

Levin, B., \& Rappaport, H. M. (1996). Lexical Semantics and Syntactic Structure. In S. Lappin (Ed.), The Handbook of Contemporary Semantic Theory (pp. 487-507). Oxford: Blackwell.

Levin, B., \& Rappaport, H. M. (2005). Argument Realization, Research Surveys in Linguistics Series. Cambridge, UK: Cambridge University Press. https://doi.org/10.1017/CBO9780511610479

Masica, C. (1976). Defining Linguistic Area: South Asia. Chicago: The University of Chicago Press.

Nedjalkov, V. P. (1969). Nekotorye verojatnostnye universalii v glagol'nom slovoobrazovanii. In I. F. Vardul (Ed.), Jazykovye universalii i lingvisticheskaja tipologija (pp. 106-114). Moscow: Nauka.

Nedjalkov, V. P., \& Silnitsky, G. G. (1973). The typology of morphological and lexical causatives. In K. Ferenc (Ed.), Trends in Soviet theoretical linguistics (pp. 1-32). Dordrecht: D. Reidel Publishing. https://doi.org/10.1007/978-94-010-2536-2_1

Nomura, M. (1985). The system of the Japanese language-proceedings. Izumi Publishing Company.

Rappaport, H. M., \& Levin, B. (1998). Building Verb Meanings. In M. Butt \& W. Geuder (Eds.), The Projection of Arguments: Lexical and Compositional Factors (pp. 97-134). Stanford, CA.: CSLI Publications.

Rappaport, H. M., \&Levin, B. (2010). Reflections on Manner/Result Complementarity. In E. Doron, M. Rappaport Hovav \& I. Sichel (Eds.), Syntax, Lexical Semantics, and Event Structure (pp. 21-38). Oxford, UK: Oxford University Press. https://doi.org/10.1093/acprof:oso/9780199544325.003.0002

Ueta, N. (2008). A general study on Mongolian's vowel system. Dissertation, Kyoto University.

\section{Notes}

Note 1. The World Atlas of Transitivity Pairs (2014). Tokyo: National Institute for Japanese Language and Linguistics (Available online at: http://verbpairmap.ninjal.ac.jp), hereafter: WATP.

Note 2 . The inchoative verb is the base, the causative verb is derived by attaching a bound morpheme to the inchoative verb roots.

Note 3 . The causative verb is the base and the inchoative verb is derived by attaching a bound morpheme to the causative verb roots.

Note 4. These are the bound morphemes that realise causative/inchoative verb alternation. The base root is in bold. The token number is inside the brackets ( ).

Note 5 . Here, the inchoative verb is the base, the causative verb is derived by attaching a bound morpheme to the inchoative verb root.

Note 6 . The causative verb is the base and the inchoative verb is derived by attaching a bound morpheme to the causative verb roots.

Note 7. The map is drawn from http://user.keio.ac.jp/ rhotta/hellog/2013-07-23-1.html

Note 8 . The diversity lies in the physical positions that make sounds. 
Note 9. man'yōgana is writing in Man'yōshū (the oldest collection of Japanese poetry), where three patterns borrowed Chinese characters are used: (a) solely borrowing semantic meaning (logographic writing); (b) solely borrowing phonological value (phonographic writing); and (c) borrowing both semantic and phonological values.

\section{Copyrights}

Copyright for this article is retained by the author, with first publication rights granted to the journal.

This is an open-access article distributed under the terms and conditions of the Creative Commons Attribution license (http://creativecommons.org/licenses/by/4.0/). 